\title{
Weonomics
}

Central European Review of Economics \& Finance

Vol. 25, No. 3 (2018), pp. 5-19

DOI: $10.24136 /$ ceref.2018.012

Received: 4 January 2018. Accepted: 2 May 2018

Krzysztof WITKOWSKI ${ }^{1}$, Mateusz KUROWSKI ${ }^{2}$, Dariusz LESICKI ${ }^{3}$

\section{CSR IN AUTOMOTIVE SECTOR - LEADERS OR DECEIVERS? THE CASE OF AUDI AG}

Car production is a kind of activity that affects environment, society and global economy to a large degree. The most negative impact can be observed in the first of mentioned fields. Every day automotive companies consume big amount of energy and resources. What is more, their final products are considered as one of the main pollution sources. Nevertheless many car producers made effort to minimize negative external effects of their businesses. Year by year various CSR classifications and rankings showed that those efforts were resulfful but Volkswagen emissions scandal and anti-diesel lobby shed new light on car industry in the terms of CSR. The aim of the article is to review CSR activities undertaken by Audi AG. Literature review and report analysis performed within the case study shows that the company is active in the field of ecology, society and corporate governance. In many terms Audi AG can be considered as the one of global CSR leaders. It is characterized by wide range of long term initiatives, high employee satisfaction and constant dialogue with stakeholders. On the other hand Audi AG can not be seen as a responsible company in the light of misleading customers to raise sales volume.

Keywords: CSR, automotive sector, dieselgate.

JEL Classification Codes: M14, L62.

\section{Introduction}

The main aim for each commercial player operating on the market is maximizing the profit. On the competitive market companies try to attract customers by offering higher

\footnotetext{
${ }^{1}$ Assoc. Prof., University of Zielona Góra.

${ }^{2}$ M. Sc., University of Zielona Góra.

${ }^{3}$ M. Sc., University of Zielona Góra.
} 
quality or lower prices than competitors (Porter, 1985) - in other words by acquiring competitive advantage. According to J. Kay's theory the companies which are able to win the competitive struggle are characterized by three elements. Firstly, they create and maintain positive relations with internal and external players. Secondly, they implement organizational, product and process innovations. Finally, they have good reputation which enables them to communicate necessary information to customers (Kay, 1993). Corporate reputation can not be fully controlled but it can be formed by setting reputation programs and reporting not only financial information but also data concerning other fields of company's activity.

The emphasis on organizational transparency increases with the popularity of the concept of corporate social responsibility (CSR). Companies try to outdistance each other in social and environmental actions and reach high position in CSR rankings. Some companies implement CSR tools and procedures as a marketing measure but other consider it as a way to realize their social mission. Without regard for company's attempt to CSR it takes a lot of effort to become socially responsible and to work out good relations with stakeholders. Arduously achieved position inside the society can be revised when unethical behavior, fraud or corruption practices are revealed and publicized.

On the one hand it is easy to observe positive corporate initiatives - volunteering, financing scholarships, investment in renewable energy sources, participation in various ecological and social projects. On the other hand one can still hear about using child labour, forced labour, breaching health and safety regulations or problems concerning waste processing. The problem is most common in developing countries where global supply chain leaders make pressure on suppliers to lower production costs. As one can find in the literature it concerns many companies even these with top CSR ranks in global classifications.

In the light of above findings it is difficult to state if certain company can be considered as socially responsible. There are many important aspects of activity that should be taken into consideration during evaluation.

The purpose of this article is to review CSR activities undertaken by Audi AG and to find its relationship with financial performance of the company. Research hypothesis is the idea that single unethical behavior negatively affects the company even with extraordinary CSR performance. This hypothesis was verified by report analysis and literature review. It is expected this research will provide a wide image of Audi AG's CSR performance.

Before analyzing the case of Audi AG it is necessary to take a closer look at the concept of CSR and sustainable reporting. 


\section{CSR - the concept and reporting process}

There can be found a wide variety of CSR definitions in the literature. They focus on different areas and cover various aspects of corporate activity. The problem with defining CSR results from different points of view represented by authors and institutions. They embody the field of economics, management, sociology and looking through the prism of these distinct theories it is impossible to understand the role of companies in society in the same way. This problem was noticed when the idea of CSR was developing (Votaw \& Sethi, 1973) and is still actual nowadays (Smith, 2011). The differences are also observed among geographic regions (Williams \& Aguilera, 2008). What is more in public debates CSR is sometimes used as a key word, slogan that equates for each action directed for reduction of poverty, social inequalities and environmental pollution.

As the concept of CSR itself, most its definitions base on the concept of stakeholder which is described as „any group or individual who can affect or is affected by the achievement of the organization's objectives" (Freeman, 1984, p. 46). The groups of stakeholders functioning in each organization's environment can be divided into three categories (Rodriguez, Ricart \& Sánchez, 2002):

- consubstantial - crucial for organization's functioning, e.g. workers and owners;

- contract - related with organization through formal or informal contract, e.g. clients, suppliers, competitors, financial institutions;

- contextual - essential in developing image and position in society, e.g. administration, media.

Although the first group of stakeholders are conditional for the structure and performance of the company other two are also necessary to achieve corporate goals and to become competitive. Due to Hopkins (2002) CSR is about treating all stakeholders ethically. This mission consists of two parameters. The first is to remain profitable, the second to improve living standards of the groups inside and outside organization.

Care for stakeholders was encompassed also in one of the most common definitions of CSR proposed by European Comission (2001, p. 4): „a concept whereby companies integrate social and environmental concerns in their business operations and in their interaction with their stakeholders on a voluntary basis". It means that being socially responsible means more that fulfilling law regulations what is obligatory and meeting financial expectations of shareholders what is necessary to retain the presence on the market. Due to this definition companies are expected to take into consideration also social and environmental aspects of their activity.

The new definition presented by European Commission $(2011$, p. 6) in A renewed EU strategy 2011-14 for Corporate Social Responsibility is more general and describes CSR as "the responsibility of enterprises for their impacts on society". The specific areas of responsibility are named in the further part of the document: society, environment, eth- 
ics, human rights and consumer concerns. Comparing to the previous definition minor change was made - three areas were separated from the social dimension.

Social and environmental aspects next to corporate governance constitute three pillars of CSR assessment of companies (ESG factors). Due to CFA Institute (2017) investors pay more and more attention to all three areas of ESG. $73 \%$ of respondents declare that they perform ESG analysis in at least one area and in half of these cases analysis is run systematically. Assessing ESG factors in organization requires access to specific information which can be acquired directly from the company or from sustainability reports, policies, codes of conduct, internet sites and sometimes annual reports. Publishing ESG information in documents and through media is called social reporting.

The process of social reporting entails financial expenditures, the use of specific knowledge and it requires time to prepare and update information. Companies often point out the fact that resources used to create social reporting are the main constraint in implementing this process. They follow the logic that it is better to use the resources to do something good instead of displaying previous accomplishments. This way of thinking is reasonable but without social reporting it is impossible to monitor companies performance, compare market players and to follow progress in ESG factors. What is more social reporting leads to other benefits like improved credibility, better relations with environment and positive corporate image (Lament, 2016). It is worth to mention that the biggest part of the cost of social reporting is associated with creating procedures of collecting, computing and publishing data. Since then one defined methodology evolves in time in line with new requirements and gained experience.

Research showed that in average in European countries 74 out of 100 biggest companies create sustainability report. In Americas and Asia and Pacific this count was even higher, accordingly: 77 and 79. In all three cases there has been a positive dynamic for at least 3 years. The count for Africa and Middle East was 53 and it exhibits negative tendency (KPMG, 2016a). Companies which report point out specific advantages result from this process. The first thing is improved corporate image, it also increases employee and consumer loyalty, reduces inaccurate information about the company in media and helps to refine social strategy (Ernst \& Young, 2016). Some companies also point out that CSR reporting directly affects financial aspect of their activity. They mention higher revenues and cost savings (Wolak-Tuzimek, 2016).

Unlike marketing information about undertaken projects, social reporting demands systematic and holistic approach. There are various standards and guidelines which define how socially responsible companies should behave and what should they disclose. The most popular reporting framework is Global Reporting Initiative (GRI) G4 (Ernst \& Young, 2016). It is also the most complex guideline which covers many indicators in 46 social, environmental and economic aspects.

One of the leading industries in social reporting is automotive sector (KPMG, 2016b). Thanks to this fact it is relatively easy to monitor CSR performance of the companies. 


\section{CSR in automotive sector}

After mining and technology, media, telecom (TMT), automotive is the third sector with the highest social reporting rate. Research showed that the generality of reporting goes in step with its quality (KPMG, 2016b). In average automotive companies got $65 \%$ of reporting quality points what was higher by 8 percentage points than result achieved by the whole sample of companies representing 14 sectors. The strongest points of social reporting in automotive sector are: independent assurance as a general practice and accuracy of GHG emission information - especially in scope 3 downstream. Automotive companies can be considered as a benchmark in many aspects of social reporting but there are also weaknesses. There is a problem with disclosing detailed information about e.g. environmental impact of products (KPMG, 2016b).

High level of social reporting in automotive sector is combined with good CSR performance what is confirmed by various rankings. The biggest annual CSR classification is RepTrak with a database including more than 7000 companies. In 20169 out of 100 companies with highest CSR rating represented automotive sector (Reputation Institute, 2016). It should be mentioned that it is difficult to make CSR performance comparisons between different industries because of different types of organizational structure, management styles, realized processes consequent to specific activity. For example logistics sector base on energy to perform its core business activity. It is impossible and aimless to compare freight company with banks in terms of GHG emissions and energy use. The same fact refers to social aspects of business. There is a significant demand for seasonal work in farming and tourism. In this case supporting as high social package as in the case of unfixed time contract is limited.

Automotive sector is characterized by well qualified workforce and in a result high demands from employees (Martinuzzi, Kudlak, Faber \& Wiman, 2011). The first important issue is fulfilling restrictive health and safety standards especially in production plants. Companies also try to provide measures for work-life balance but in this area there is a problem in division workers into two groups: „Facharabeiter” - with unique knowledge and qualifications and "Massenarbeiter" - with low qualifications, who work mostly on production lines. The second group states for relatively big part of workforce but the character of their job and shift work system exclude them from deriving all benefits. They can not use flexible working hours or home office. Therefore there are other measures in place e.g. funding childcare and organizing kindergartens open even during night shift. Different social problem met in automotive industry is no gender parity in general and in managerial bodies. Companies realized that fact and its negative consequences and formulate specific targets and measures in this area.

Social activity concerns more aspects than showed above and they cover also external stakeholders. Automotive companies realize their social mission also through 
investment in education, culture and sport. They also try to predict future problems with logistics, mobility, product accessibility and quality, and debate on their solutions.

The most important problem which is a consequence of car production is pollution. Automotive companies' strong point is integrating environmental targets into CSR strategy and explaining plans for their realization (KPMG, 2016b). It is caused mostly by the social pressure on limiting GHG emissions. Average air pollution caused by single car decreased between 1975 and 2000 by 95\% (Graedel, Allenby, 1998) with further negative dynamics in the XXI century. However total pollution related to car use and production grew because of high rise in the global number of cars and transport development. The specificity of automotive industry in terms of ecological footprint is the fact that the process of production is much less harmful than next phases of product lifecycle. It is important how companies produce but the crucial thing is what they produce. Thus closed water loops, efficient recycling systems, use of solar energy in factories stand for background improvements compared to modifications in car power supply.

More and more restrictive emission norms and diesel bans caused a technological pursuit among car manufacturers. Car weight reduction, straining engines and filtering combustion products have technological barriers which not always can be crossed in the short term. The moment with no progress in turbulent market of today is considered as moving backwards and losing competitive position. Practice shows that having no solution for a specific problem sometimes results in a finding shortcuts. The history of emission affairs starts in 1970's with temperature-sensing switch which affected emissions during engine warm-up period. In 1990's General Motors and Ford cars had specific engine control unit (ECU) programs which recognized test conditions and for the time of measurement it lowers the emission level (Beene, 2015). Considerable penalties and breached corporate image were not sufficient lesson for the others. In 2014 it turned out that Volkswagen Group used similar idea to misled ecological institutions and clients. Except the leader of the group - Volkswagen, other members used the same engines in their models: Porsche, Skoda, Seat and Audi which was considered as the one of the global CSR leaders.

\section{Diesel emission scandal and its consequences for Audi AG}

In 2011 European Commission's Joint Research Centre stated that all the cars powered by diesel engine they tested had higher emission levels than it is indicated in Euro 3-5 norms (Weiss et al., 2011). Usual tests performed to measure GHG emissions were detected by special programs in ECU which set the special engine mode necessary to fulfill the emission norms. This kind of manipulation could be detected only through different tests in real road conditions.

In 2014 International Council on Clean Transportation (ICCT) commissioned research on discrepancy in GHG emissions between American and European car models. Road 
tests showed that 2 out of 3 cars emited more NOx than it was previously measured in typical tests (Franco, Sánchez, German \& Mock, 2014). Real life NOx emissions were 5 to 35 times higher than in test conditions depending on a model (Thompson, 2014). Environmental Protection Agency (EPA) found the results interesting and decided to repeat tests which led to similar conclusions and in a consequence to threat of homologation withdrawal for Volkswagen and Audi 2016 models. In this case Volkswagen decided to take the responsibility and admit that it was not an error but they manipulated ECU programs knowingly (Gardner, Lienert \& Morgan, 2015).

Audi AG as a part of Volkswagen group was involved in emission scandal. $2.1 \mathrm{mln}$ Audi cars were equipped with ECU cheating mode. More than $99 \%$ of this count was sold in Western Europe including Germany and the rest in the US (Reuters, 2015). The company didn't wait long to notice first consequences.

Diesel scandal negatively influenced Audi AG's financial situation. For many years the company continued the rise in car deliveries count. Even global financial crisis could not stop the selling progress. Continuous growth was broken in 2015 when year by year deliveries dynamics was negative $(-6,74 \%)$. Lower demand translated into relatively low operating profit and inhibited revenue growth.

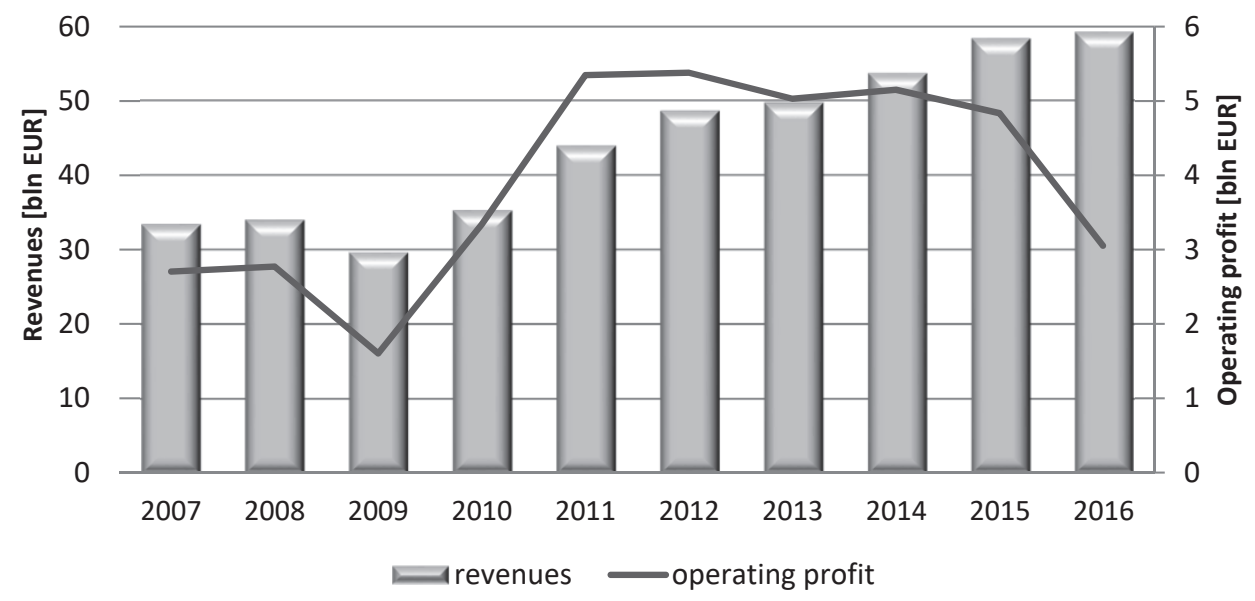

Figure 1. Revenues and operating profit of Audi AG in 2007-2016

Source: author's own work based on (Audi AG, 2009, 2011, 2013, 2015, 2017b)

Other negative financial repercussions were observed in stock market. In four day period after diesel scandal was announced Audi AG share prices fell by $18,2 \%$. It reached its bottom in the first week of October 2015 with the total drop of a quarter. Two years turned out to be too short time for Audi AG shares to come back to prescandal price level. In November 2017 it managed to make up a half of the diesel scandal loss. For Audi AG it has been the biggest and the longest share slump since global financial crisis 
started in 2007 . Then, in the first four days of the crisis share prices fell by $12,1 \%$ but the total drop was $60,1 \%$ in 16 months.

Audi AG will also wait for other financial repercussions to come. There is no official announcement on predicted costs of buy-backs, lease terminations and service actions, because it all depends on customers' decision. Theoretically the best option for Audi AG in terms of expenses is customers' acceptance of loading new program into ECU but then they also have to make payout depending on car value. What is more it is unknown if Audi AG will participate in penalties as a member of Volkswagen Group. The case is under investigation in many countries. For example in the USA Volkswagen Group will pay $\$ 4.7$ bln for mitigation of GHG emissions effects and for supporting clean emission projects (Shepardson, 2017). By far there is no information what part will be paid by Audi AG.

Apart from financial consequences there are more negative side effects of engine mode manipulation for Audi AG. Higher NOx emissions are calculated for premature deaths and disability-adjusted life years (Barrett et al., 2015). The fraud affected something more than product durability, driving satisfaction and economical aspect of purchase, it lowered life quality of the society in general. Clients lost their trust in brand and its products.

Single fraud can undermine responsible attitude demonstrated during years of activity. Audi AG is an example of incoherent behavior which caused that all positive CSR aspects are now behind the latest incident.

\section{Audi CSR performance}

"Sustainability of products and processes" (Audi AG, 2015, p. 5) is Audi AG's strategic goal. Measures taken to realize it were worthwhile what was affirmed by high CSR ratings and prizes. In 2014 Audi AG was voted as the most sustainable German company (Audi AG, 2015). Year by year it is also considered as one of the best employers: the most attractive employer for engineering students, second-best for future economists, fourth for computer scientists. Audi AG was also called the best German employer in automotive industry (Audi AG, 2017c). This image consists of many elements from the field of ecology, social engagement and corporate governance. Being responsible pledges to set challenging but feasible targets in above areas and to plan the way to reach them.

In terms of ecology reduction of GHG emissions is the priority for automotive companies. Audi AG set the goal of limiting total emissions by $25 \%$ between 2010 and 2018 (Audi AG, 2017c). This goal seems to be reasonable but in case of rapid growth in production it can be impossible to reach despite noticeable progress in limiting GHG emissions. In this case it is better to take account of emission intensity per one vehicle. In 2010 it was $1030 \mathrm{~kg}$ per car and the count fell by $37 \%$ till 2016 . 
Realization of the reduction plan base on specific actions e.g. using railway transport powered by renewable energy sources in $60 \%$ of car deliveries, closing the loop of aluminium (Audi AG, 2017c) or using engine break-in process to heat the company buildings. Audi AG also try to limit scope $3 \mathrm{GHG}$ emissions which are the biggest part of total emissions in automotive sector. There are some projects realized which can begin significant changes in private transportation system like developing hydrogen powered cars and energy supply infrastructure (Audi AG, 2017a). There are also projects which seemed to be only an ecological detail and turned out to be a significant possibility. Sunroof with solar panels has been mounted in cars as the energy source for cooling car interior when the engine is off. After years of developing solar panels technology in 2017 there is a plan to mount high effective solar panel on the roof of a car to provide energy for the engine (Audi Media Center, 2017).

GHG emissions is a result of fuel combustion in energy generation process. The use of energy is the second most important aspect of environmental activity of automotive companies. Audi AG set up a goal of reducing energy use intensity in production sites by $25 \%$ between 2010 and 2018. In 2016 it was still far from reaching the appointed level but the reduction by $8,4 \%$ is also significant (Audi AG, 2015; 2017b). In this case measures dedicated to reduce $\mathrm{GHG}$ emissions are also helpful. Additionally it is worth to mention actions which lead not only to change in the energy sources but to mitigation of energy use. $95 \%$ of parts and materials in typical Audi car can be recycled. It limits the need of production of new materials and semi-products (Audi AG, 2017c). Audi AG also realizes the determination of reducing the weight of models in each succeeding generation (Audi AG, 2017a).

The next important environmental factor is water use. In this area Audi AG plans to reduce the intensity by $25 \%$ in the period from 2010 till 2018. In previous years square meters required to produce a single car varied. It was decreasing till 2014 to reach the level of 2 and then it started to increase to 2,27 in 2016. The recent tendency is not promising but it is expected to change after activation of membrane bioreactor which will turn wastewater into freshwater in Ingolstadt production plant. There will also be a new water purification plant opened in Mexico (Audi AG, 2017b).

Except environmental actions Audi AG's strategy cover numerous social undertakings. Since 2012 it has been a member of United Nations Global Compact Initiative (Audi AG, 2013). It's code of conduct is created in accordance to International Labour Organization's conventions and it covers 26 issues important for employees (Audi AG, 2017d). Moreover there is a special human rights policy in place (Audi AG, 2017d). In a case of code of conduct breach or other unethical practices employees can use anonymous reporting channels. Working conditions are monitored for example by anonymous employees' satisfaction surveys which covers $70 \%$ of the workforce in Germany (Audi AG, 2017b). In 2016 94\% of surveyed considered Audi AG as an attractive 
employer what complements expectations of students taking part in mentioned earlier surveys on potential future employers.

In terms of occupational health and safety the most important statistic is the accident rate. In 2016 there were 4.0 work-related accidents for million hours worked (Audi AG, 2017b) what is a positive result comparing to main market competitors (BMW AG, 2017; Daimler AG, 2017). Above typical health and safety measures there has been Audi Checkup program run since 2006. All employees can use help in detecting and mitigating health threats during their working time. In $201690 \%$ of workforce took a part in this project (Audi AG, 2017b).

Audi AG pays attention also to work-life balance supporting employees in childcare centers and flexible work possibilities. Those who return to the workplace after maternity and other long kinds of leave are reintroduced into duties through Job and Family Program. In 2016 company's management and General Works Council undersigned agreement on mobile work. What is important there is no distinction in access to benefits between full-time and part-time and temporary employees. It can only be limited by work character. For example when it comes to flexible work plans part-time employees working on a shift system on a production line are able to modify the time schedule or to choose the only satisfying shift (Audi AG, 2017b). Due to Charter on Temporary Work for the Volkswagen Group (Volkswagen AG, 2012) which covers also Audi AG, temporary workers have the right to equal pay an access to training programs. Signing permanent contracts with temporary employees is the one out of three base hiring paths for Audi AG. In 2016433 temporary workers became permanent staff members (Audi AG, 2017b).

Employees are the most important stakeholder group for Audi AG, because their work leads to final market success or failure. In organizational environment there are more groups of stakeholders which affect Audi AG's activity. Audi Stakeholder Forum is a tool for finding out the needs of society, current and future problems of automotive market, logistics, environment and society in general. Annual meetings held in Ingolstadt gathers up to 100 representatives of various stakeholders groups who discuss important topics and help Audi AG to realize its social mission. During the last meeting guests and company's management gave attention to electric mobility - its perspectives and development in Europe (Audi AG, 2017b). Similar projects are run also in foreign business locations. For stakeholders worldwide there is also an online sustainable portal for communications and contact.

Sometimes communication is not enough to help certain groups in society and direct financial support is needed. Audi AG as the company and its employees run or participate in single actions e.g. for disaster victims and run long term charity projects. In Last Cents program employees voluntarily accept salary payment rounded down to full euro. The remaining cents are handed to social organizations. In 2016 workers gathered more than $1.2 \mathrm{mln}$ EUR this way (Audi AG, 2016). 99\% of workforce in main 
factories located in Ingolstadt and Neckarsulm participated in a Christmas donation. The total sum doubled by the company donation was 960000 EUR. There are many other examples of donations but it is unclear what is the total donation in previous year. A part of this sum is spent on education through financing lectures, courses and scholarships. For examples more than 140 doctoral candidates pursued their doctorates in projects financed by Audi AG. It also funds school program for young refugees helpful in getting educational background and knowledge about German culture (Audi AG, 2015). Direct help is also realized by volunteering programs. Audi AG allows workers to participate in social projects during working time. Audi Volunteers program stand for 30400 hours of work under 440 social initiatives (Audi AG, 2016).

Another aspect of CSR is corporate governance. One of the main important issues in this area is independence of management and supervisory bodies. In Audi AG board of directors is independent as existing audit committee. The negative point is the lack of nominating and remuneration committee (Audi AG, 2017a).

Individual remuneration of the members of supervisory board and board of management is presented in detailed report and it includes different components: fixed remuneration, fringe benefits, one-year and multi-year variable remuneration, and pension expenses (Audi AG, 2017a). The principles of calculating bonuses is also disclosed, but there is no information about the average salary so the ratio highest to average remuneration can not be calculated. Audi AG supports equal remuneration, working conditions and benefits for male and female workers.

Audi AG as an automotive company hires mostly male employees. Women stand for $14.9 \%$ of total workforce and $9.5 \%$ of managers and in both cases the trend is positive. In last two years mentioned indicators increased accordingly by 0.7 and 1.2 percentage points (Audi AG, 2017b). There are no females in the board of managers. The company goal is to reach $8 \%$ of women in top management and $18 \%$ in second tier management by the end of 2021. Exemplary measures are: educational camps for female students, cooperating with women's networks and organizing internships where $30 \%$ of participants are female what is the highest rate in the industry (Audi AG, 2017b).

What is also worth mentioning is the quality of social reporting in Audi AG. All relevant documents and reports concerning CSR issues are disclosed online and they are also available in printed version in company headquarters. Sustainability Report 2016 is compatible with GRI G4 guidelines what simplifies searching of necessary information. Disclosed data is up-to-date and in most cases it is presented in at least 3 year timeline what allows to set down the trend of the parameter. Audi AG also uses reliable methods of collecting data e.g. Greenhouse Gas Protocol and the information is assured by independent body (Audi AG, 2017b). The coverage of data is clearly specified, wide and there are no accidental changes what could suggest the data manipulation. 


\section{Conclusion}

CSR impact on financial aspects of company's activity is often questioned. The case of Audi AG shows that customers' reaction on specific corporate practices can significantly influence financial condition of the company at least in short term. Audi AG was known as a company with high CSR performance. Involvement in emission scandal resulted in rapid share price drop. The year after fraud was announced, the positive trend of car deliveries continued for at least 8 previous years, was broke. It did not happen even during last global financial crisis when automotive industry was affected by many problems including decline of demand. Customers lost their trust in brands who cheated in emission tests and time will show if the image can be recovered.

Assessment of the CSR performance of the company should consist of two elements. The first is CSR alert monitoring - incidents like breach of law, human rights, environmental rules etc. The second is a fundamental analysis of CSR documents and reports. This is the only way to get the wide picture of company's responsibility. Materials disclosed by the company is a description of how it is managed and what processes are realized within its organizational borders. CSR alert monitoring is a practical verification of what company declares in documents.

Automotive companies set out standards in many CSR aspects. For example their reporting is relatively high quality and they pay a lot of attention to $\mathrm{GHG}$ emissions. Many car manufacturers are classified on the top positions in CSR rankings. Nevertheless they still need many improvements in their CSR strategies. Volkswagen Group case is an evidence that automotive sector is not free from fraud, manipulations and spreading false information. What is more later research showed that emission cheating programs is a common problem in the industry (Department for Transport, 2016).

A remark about social reporting should also be made. This is a process which requires certain amount of resources but it is the only way to communicate CSR data. It is a source of information necessary to make non-financial assessments of the company, comparative analysis and to monitor the progress in important indicators. Social reporting should be considered not as a voluntary action to present own advantages but as a part of social duty.

\section{References}

Audi AG. (2009). Audi Annual Report 2008. Ingolstadt, Audi AG. Retrieved from https://www.audi.

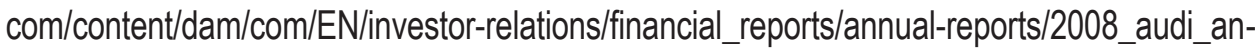
nual_report.pdf (access 12.12.2017).

Audi AG. (2011). Audi Annual Report 2010. Ingolstadt, Audi AG. Retrieved from https://www.audi.

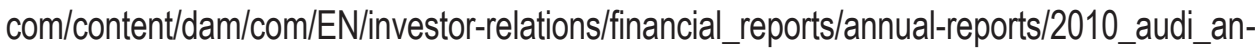
nual_report.pdf (access 12.12.2017). 
Audi AG. (2013). Audi Corporate Responsibility Report 2012. Ingolstadt, Audi AG. Retrieved from http://www.audi.com/content/dam/com/corporate-responsibility/Audi_CR-Report_2012_Englisch_Printversion.pdf (access 12.12.2017).

Audi AG. (2015). Audi Corporate Responsibility Report 2014. Ingolstadt, Audi AG. Retrieved from https:/www.audi.com/content/dam/com/EN/corporate responsibility/audi_cr_report_2014_ en.pdf (access 12.12.2017).

Audi AG. (2016). Audi Annual Report 2015. Ingolstadt, Audi AG. Retrieved from https://www. audi.com/content/dam/com/EN/investor-relations/financial-events/annual-general-meetings/2017/3.1_GB_2015_en.pdf (access 12.12.2017).

Audi AG. (2017a). Audi Annual Report 2016. Ingolstadt, Audi AG. Retrieved from https://www. audi.com/content/dam/com/EN/investor-relations/financial_reports/annual-reports/ar-2016. pdf (access 12.12.2017).

Audi AG. (2017b). Audi Sustainability Report 2016. Ingolstadt, Audi AG. Retrieved from http:// www.audi.com/content/dam/com/corporate-responsibility/170518_AUD_NH_Bericht_2016_ EN_Nur_Bericht.pdf (access 12.12.2017).

Audi AG. (2017c). Code of Conduct. Ingolstadt, Audi AG. Retrieved from https://www.audi.com/ content/dam/com/corporate-responsibility/nachhaltigkeit_pdfs/audi-code-of-conduct-english . pdf (access 12.12.2017).

Audi AG. (2017d). Statement of Principles concerning Respect for and Observance of Human Rights. Ingolstadt, Audi AG. Retrieved from https://www. audi.com/content/dam/com/corporateresponsibility/society/Audi_Statement_of_Principles_Human_Rights_2017_final.pdf (access 12.12.2017).

Audi Media Center. (2017). Audi models with a solar roof: Car manufacturer cooperates with Hanergy. Retrieved from https://www.audi-mediacenter.com/en/press-releases/audi-modelswith-a-solar-roof-car-manufacturer-cooperates-with-hanergy-9221 (access 12.12.2017).

Barrett, S., Speth, R. L., Eastham, S. D., Dedoussi, I. C., Ashok, A., Malina, R. \& Keith, D. W. (2015). Impact of the Volkswagen emissions control defeat device on US public health. Environmental Research Letters, 10(11), 1-10.

Beene, R. (24 September 2015). VW emissions 'defeat device' isn't the first. Retrieved from autoweek.com/article/car-news/vw-emissions-defeat-device-isnt-first (access 12.12.2017).

BMW AG. (2017). Sustainable Value Report 2016. Munich: BMW AG. Retrieved from https:// www.bmwgroup.com/content/dam/bmw-group-websites/bmwgroup_com/ir/downloads/ en/2016/BMW-Group-SustainableValueReport-2016--EN.pdf (access 12.12.2017).

CFA Institute. (2017). Environmental, social and governance (ESG) survey. Charlottesville, CFA Institute.

Daimler AG. (2017). Sustainability Report 2016. Stuttgart, Daimler AG. Retrieved from https:// www.daimler.com/documents/sustainability/other/daimler-sustainability-report-2016.pdf (access 12.12.2017). 
Department for Transport. (2016). Vehicle Emissions Testing Programme. London, Department for Transport.

Ernst \& Young. (2016). Value of sustainability reporting. London, Ernst \& Young.

European Commission. (2001). Green Paper: Promoting framework for Corporate Social Responsibility. Brussels, European Commission.

European Commission. (2011). A renewed EU strategy 2011-2014 for Corporate Social Responsibility. Brussels, European Commission (25.10.2011 COM(2011)681 Final).

Franco, V., Sánchez, F. P., German, J. \& Mock, P. (2014). Real-world exhaust emissions from modern diesel cars. Berlin, ICCT.

Freeman, R. E. (1984). A stakeholder approach to strategic management, Boston, Pitman.

Gardner, T., Lienert, P., \& Morgan, D. (24 September 2015). INSIGHT-After year of stonewalling, VW stunned US regulators with confession. Retrieved from https://www.reuters.com/article/ usa-volkswagen-deception/insight-after-year-of-stonewalling-vw-stunned-us-regulators-withconfession-idUSL1N11U1OB20150924 (access 11.12.2017).

Graedel, T., \& Allenby, B. (1998). Industrial ecology and the automobile. Upper Saddle River, Prentice-Hall International.

Hopkins, M. (2002). CSR and Global Business Principles: What a Mess!. Retrieved from http:// citeseerx.ist.psu.edu/viewdoc/download?doi=10.1.1.200.3755\&rep=rep1\&type=pdf (access 12.12.2017).

Kay, J. (1993). The structure of Strategy. Business Strategy Review, 4(2), 17-37.

KPMG. (2016a). Carrots \& Sticks. Amselveen, KPMG.

KPMG. (2016b). Corporate responsibility reporting in the automotive sector. Amsleveen, KPMG.

Lament, M. (2016). CSR Reporting in Financial Institutions. Central European Review of Economics \& Finance, 13(3), 65-81.

Martinuzzi, A., Kudlak, R., Faber C., \& Wiman, A. (2011). CSR Activities and Impacts of the Automotive Sector. RIMAS Working Papers, 3, 1-31.

Porter, M. E. (1985). Competitive Advantage. New York, Free Press.

Reputation Institute. (2016). 2016 Global RepTrak 100. Cambridge, Reputation Institute.

Reuters. (28 September 2015). Audi says 2.1 million cars affected by diesel emission scandal.

Retrieved from https://www.reuters.com/article/us-volkswagen-emissions-audi/audi-says2-1-million-cars-affected-by-diesel-emission-scandal-idUSKCNORSOY720150928 (access 12.12.2017).

Rodriguez, M. A., Ricart, J. E., \& Sánchez P. (2002). Sustainable Development and the Sustainability of Competitive Advantage: A Dynamic and Sustainable View of the Firm. Creativity \& Innovation Management, 11(3), 135-146.

Shepardson, D. (2016). U.S. judge approves $\$ 14.7$ billion deal in VW diesel scandal. Retrieved from $\mathrm{https://www.reuters.com/article/us-volkswagen-emissions/u-s-judge-approves-14-7-bil-}$ lion-deal-in-vw-diesel-scandal-idUSKCN12P22F (access 11.12.2017). 
Smith, R. E. (2011). Defining Corporate Social Responsibility: A Systems Approach For Socially Responsible Capitalism. Master of Philosophy Theses. 9.

Thompson, G. J. (2014). In-Use Emissions Testing of Light-Duty Diesel Vehicles in the United States. Morgantown, CAFEE.

Volkswagen AG. (2012). Charter on Temporary Work for the Volkswagen Group. Wolfsburg: Volkswagen AG. Retrieved from http://ec.europa.eu/social/PDFServlet?mode=tca\&agreemen tld=201\&langld=en (access 12.12.2017).

Votaw, D. \& Sethi, S. P. (1973). The Corporate Dilemma: Traditional Values versus Contemporary Problems. New York, Prentice Hall.

Weiss, M., Bonnel, P., Hummel, R., Manfredi, U., Colombo, R., Lanappe, G., Le Lijour, P., \& Sculati, M. (2011). Analyzing on-road emissions of light-duty vehicles with Portable Emission Measurement Systems (PEMS) (EUR24697 EN). Brussels, European Commission.

Wolak-Tuzimek, A., (2016). Benefits of introducing the concept of corporate social responsibility to enterprises. Central European Review of Economics \& Finance, 14(4), 5-23. 